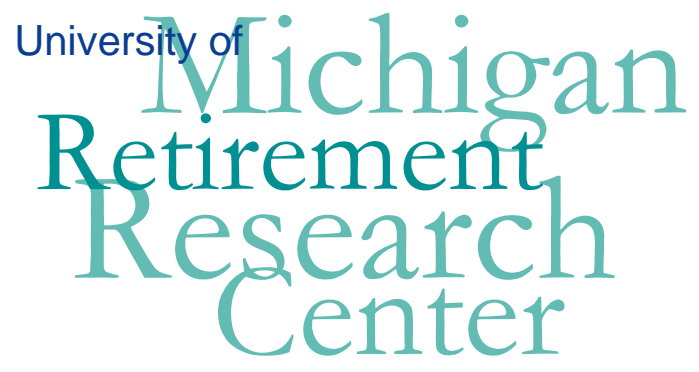

Working Paper

WP 2006-110

\title{
Consumption and Economic Well-Being at Older Ages: Income- and Consumption- Based Poverty Measures in the HRS
}

Michael Hurd and Susann Rohwedder

\begin{tabular}{|l|l|}
\hline $\mathrm{M}$ & $\mathrm{R}$ \\
\hline $\mathrm{R}$ & $\mathrm{C}$ \\
\hline
\end{tabular}$\quad$ Project \#: UM05-08 


\title{
"Consumption and Economic Well-Being at Older Ages: Income- and Consumption-Based Poverty Measures in the HRS”
}

\author{
Michael Hurd \\ RAND and NBER \\ Susann Rohwedder \\ RAND \\ January 2006 \\ Michigan Retirement Research Center \\ University of Michigan \\ P.O. Box 1248 \\ Ann Arbor, MI 48104 \\ http://www.mrrc.isr.umich.edu/ \\ (734) 615-0422
}

\section{Acknowledgements}

This work was supported by a grant from the Social Security Administration through the Michigan Retirement Research Center (Grant \# 10-P-98358-5). The findings and conclusions expressed are solely those of the author and do not represent the views of the Social Security Administration, any agency of the Federal government, or the Michigan Retirement Research Center.

\section{Regents of the University of Michigan}

David A. Brandon, Ann Arbor; Laurence B. Deitch, Bingham Farms; Olivia P. Maynard, Goodrich; Rebecca McGowan, Ann Arbor; Andrea Fischer Newman, Ann Arbor; Andrew C. Richner, Grosse Pointe Park; S. Martin Taylor, Gross Pointe Farms; Katherine E. White, Ann Arbor; Mary Sue Coleman, ex officio 


\title{
Consumption and Economic Well-Being at Older Ages: Income- and Consumption-Based Poverty Measures in the HRS
}

\author{
Michael Hurd \\ Susann Rohwedder
}

\begin{abstract}
According to economic theory, well-being or utility depends on consumption. However, at the household level, total consumption is rarely well measured because its collection requires a great deal of survey time. As a result income has been widely used to assess well-being and poverty rates. Yet, because households can use wealth to consume more than income, so an income-based measure of well-being could yield misleading results for many households.

We use data from the Health and Retirement Study to find income-based poverty rates which we compare with poverty rates as measured in the Current Population Survey. We use HRS consumption data to calculate a consumption-based poverty rate and study the relationship between income-based and consumption-based poverty measures. We find that a poverty rate based on consumption is lower than an income-based poverty rate. Particularly noteworthy is the much lower rate among the oldest single persons such as widows. The explanation for the difference is the ability to consume out of wealth.
\end{abstract}

\section{Authors’ Acknowledgements}

We gratefully acknowledge research support from the Social Security Administration via the Michigan Retirement Research Center, and additional support for data development from the National Institute on Aging. We would like to thank John Phillips and Eugene Steuerle for insightful comments. 


\section{Introduction}

According to economic theory, well-being or utility depends on consumption and possibly other inputs such as leisure. However, at the household level total consumption is rarely well measured because its collection requires a great deal of survey time. ${ }^{1}$ As a result income has been widely used to assess well-being and poverty rates. Because households can use wealth to consume more than income or save to consume less than income, an income-based measure of well-being could yield misleading results for many households. As argued in a number of studies consumption is therefore a better measure than income for assessing material well-being and poverty status (Cutler and Katz, 1991; Jorgenson and Slesnick, 1987; Mayer and Jencks, 1993; Slesnick, 1993, 1994, 2001; Jorgenson, 1998; Garner and Short, 2001; Johnson, Smeeding, and Torrey, 2005; Meyer and Sullivan, 2003; Rogers and Gray, 1994; Zaidi and de Vos, 2001). For example, an elderly household with low income and substantial wealth can be expected to spend part of its wealth to finance greater consumption than its income, and so it would have a higher standard of living than would be indicated by its income. Furthermore, income does not capture flows of utility derived from owner-occupied housing and other durables that a household might own (Federman et al., 1996; Garner and Short, 2001, 2005; Slesnick, 1994).

Even among households that are liquidity constrained and so could be presumed simply to consume their income, the difference can be important. For example, Meyer and Sullivan (2003) find that among such households income is a poor indicator of well-being due to transfers from outside the household and systematic underreporting of income among welfare recipients. Furthermore, income is subject to transitory shocks which households are largely able to smooth so that consumption is more stable than income (Sabelhaus and Groen, 2000). The differences between income and consumption have important implications for policy because they affect assessments of poverty rates and the adequacy of economic resources for the elderly.

The two primary data sources for previous studies of consumption-based measures in the United States are the Consumer Expenditure Survey (Cutler and Katz, 1991; Federman et al. 1996; Fernandez-Villaverde and Krueger, 2002; Garner and Short, 2001; Jorgensen 1998; Meyer and Sullivan, 2003; Rogers and Gray, 1994; Sabelhaus and Groen, 2000; Short et al., 1998; Slesnick 1993 \& 1994) and the Survey of Income and Program Participation (Bauman 1998, Bauman, 2003,

\footnotetext{
1 The Consumer Expenditure Survey (CEX), which has the most comprehensive measure of consumption in the U.S., lacks a number of important household characteristics, and its measure of income is crude.
} 
and Short et al.,1998). Neither one of these surveys have sufficient detail to assess poverty taking into account all resources available to the household: while the Consumer Expenditure Survey (CEX) has the most detailed and comprehensive measure of household spending its income measure has known weaknesses and a measure of total net worth is not available; the Survey of Income and Program Participation (SIPP) only has partial measures of spending and the wealth measure has problems.

Our contribution to this literature will be an analysis of newly available data which contain high quality measures of income, wealth and consumption, as well as many other characteristics of the same households. We use data from the Health and Retirement Study (HRS), a biennial longitudinal survey of about 20,000 persons aged approximately 51 or older. In the core survey the income and wealth of the household are measured using innovative techniques that arguably yield better measures of economic resources than in prior surveys. Of particular importance for this research is that a substantially complete measure of spending was assessed for a large random subset interviewed by HRS in the 2000 wave. Thus we will be able to study consumption- and income-based measures of economic well-being and relate the difference to wealth. No other household survey permits such analyses.

Because the single most important indicator of economic distress is the poverty rate, in this paper we will compare poverty rates based on income with poverty rates based on consumption. In that we will want to relate the consumption-based poverty rates to official income-based poverty rates, we will begin by a comparison of the income-based poverty measure in the HRS with the corresponding measure in the Current Population Survey (CPS). The CPS is the source for the official poverty measure in the U.S. and we want to establish whether any difference between our consumption-based measure and the official poverty rate is due to anomalies in the two surveys or due to the populations covered. Then we will study the relationship between income-based and consumption-based poverty measures in the HRS, and we will relate the differences to a number of characteristics. In particular we will find whether there are important wealth differences that could explain why a household is in poverty according to income but not according to consumption. Our main emphasis will be on poverty status following retirement because of the concern about the high poverty rate among older single people, in particular older widows. Furthermore, the causes of poverty are different before and after retirement. Prior to retirement, poverty is mainly related to employment either because of very low wage rates or unemployment. After retirement poverty is 
due to inadequate saving, survival into advanced old age, and possibly unexpected health care expenditures, as well as inadequate income.

\section{Official Poverty Measure}

In this section we will discuss the official definition of poverty and how its measurement is accomplished in the CPS. We will point out some practical measurement issues. Our purpose is to show that, as implemented in the CPS, poverty status could be measured with considerable error, which will complicate the comparisons with a poverty measure based on the HRS.

\subsection{Definition and Measurement}

The official poverty measure classifies an individual as "in poverty” if the individual lives in a household whose total annual pre-tax money income is below the poverty threshold. An abbreviated schedule of the poverty thresholds is in Table 1. A notable feature is that the poverty threshold is lower for households in which the head is over 65, and that it differs according to the number of people in the household. Thus the poverty rate will depend on living arrangements. Poverty status does not depend on income-in-kind such as food stamps or Medicare, ownership of consumer durables especially housing, or wealth.

In the U.S. the poverty status of a sample of households is assessed in the Annual Social and Economic Supplement (ASEC) to the CPS which has historically been referred to as the March Supplement to the CPS. ${ }^{2}$ One person, the "respondent," also referred to as the "householder," answers for all people in the household. The relationships among the household members are defined by their relationship to the reference person, who is generally the owner or renter of the dwelling unit and so is known as the householder. The respondent and the reference person need not be the same.

The respondent is asked whether any person in the household has income from a list of income sources; who has the income (which is matched against a household roster); what is the most comfortable reporting period for the income item (week, month etc); and the amount of income that each household member has from that source. If, when annualized, the amount seems too large, the respondent is asked whether the amount seems about right, and is possibly re-asked.

\footnotetext{
${ }^{2}$ An additional small number of interviews for the ASCE are given in February and April.
} 


\subsection{Measurement Issues in the CPS}

Except for income from assets the CPS components of income are shown in Table 2. We note that the list is rather lengthy, that the income items have to be recorded for each individual, and that a reporting period is asked about each item. We bring these points up to point out that there is considerable opportunity for reporting errors and for item nonresponse. We will return to the issue of item nonresponse below.

Asset income is divided into three groups: interest, dividends and rent. They are queried in the following manner (which we have paraphrased somewhat):

\section{Interest income}

"Did anyone in your household have money in savings accounts or money market funds?”

"Did anyone have bonds, T-notes, IRAs or CDs?"

"Did anyone have an interest-earning checking account or other investments that pay interest?”

If "yes" to any of these queries, by HH member and by the most comfortable reporting period the respondent is asked the amount of interest income in total from these sources. The total is annualized depending on the reporting period.

\section{Dividends}

"Did anyone own stocks or mutual funds?"

If "yes," by HH member and by the most comfortable reporting period the respondent is asked the amount of dividend income in total from these sources. The total is then annualized.

\section{Rental income}

"Does anyone own land rented out, apartments etc?"

"Royalties, roomers?"

"Estates or trusts?”

If, "yes" to any of these queries, by HH member the respondent is asked the amount of income from these sources in most comfortable reporting period. Then total is then annualized. 
Item nonresponse for earnings items which includes income from capital is $12.4 \%$ overall but much higher for some items. Missing values are imputed using hotdeck with demographic and economic stratification. We note that this type of imputation will reproduce population averages, but it is not very good for imputation for the income items of a household that is in the tail of the distribution: covariates have limited power to put values in tails of distributions. An implication is that the CPS will underestimate poverty if low-income elderly have interest-paying assets because their income will be imputed toward the median of the population distribution which is likely to be an overestimate of income from that source.

\section{Implementation of an Income-Based Poverty Measure in the HRS}

\subsection{Measurement of Income in the HRS}

The HRS uses a "financial respondent," to report about income and asset items for the spouse and for others in the household. The financial respondent is selected by the household in response to a question about who is most knowledgeable regarding the finances of the household. An important difference from the CPS is that the HRS is a person-based survey not a household survey. This difference can be important when assessing the poverty status of individuals who are living in multi-person households. For example, consider an elderly widow living with her daughter and son-in-law who are the owners of the house. In the CPS the daughter or son-in-law would report on household income including the income of the widow. Because it is likely that the son-in-law and daughter have income that would put the household above the poverty line, a lack of knowledge about the widow's income would not be important in determining the household's poverty status. In the HRS the widow reports for herself. The daughter and son-in-law are other people in the household so the widow reports for them as well. To the extent that she under-reports their income (about which she may have little information), the household may be incorrectly classified into poverty. Thus, in this example, we would get better reports in the CPS format about total household income and poverty status, but worse information about the income of the widow. 


\section{Income items measured in HRS}

The individual items are about the same as in the CPS, so we just give a somewhat aggregated list. ${ }^{3}$

Earnings (sum of a number of components)

Capital income (sum of a number of components)

Pension and annuity income (sum of a number of components)

Social Security SSI and SSDI

Social Security retirement benefits (worker, spouse, widow(er))

Unemployment and workers compensation

Government transfers (sum of veterans benefits, welfare, food stamps)

Other household income (sum of a number of components)

\subsection{Measurement Issues in the HRS}

When comparing CPS poverty rates with HRS poverty rates an additional complication is the "age" of the household. In the CPS the age is the age of the reference person, the so-called "householder." The HRS does not define a householder. The age of the household is important for two reasons: the poverty line is different when the householder is 65 or over; we would like to compare poverty rates by age which requires a classification by age of householder. We will use the age of the male as an approximation, but we have no good way to assess any bias that may result from this.

An additional measurement problem is household income in composite households. HRS asks a large number of questions about the income of the core HRS household members, the ageeligible individual and the spouse of the age-eligible individual. However, poverty status also depends on the incomes of non-core HRS household members such as children or parents of the core HRS household members. The HRS asks about the earnings of each non-core household member with follow-up brackets but then has just one question about all other income of all non-

\footnotetext{
${ }^{3}$ For example, capital income includes income from four categories of financial assets each queried separately, income from a farm or business, and income from real estate.
} 
core household members with a follow-up bracketing questions. There are four bracket boundaries, $\$ 2,000, \$ 10,000, \$ 20,000, \$ 50,000$, which define five bracket intervals. Even within one of the lower brackets, however, an imputation toward the upper end of an interval may be enough to lift the household out of poverty.

We do not know the overall effect of this method compared with the CPS method. In the CPS the respondent reports about detailed income details for each household member. Hotdeck with covariates is used to impute for item nonresponse.

\subsection{Innovations in survey methods in HRS particularly relevant to measuring income}

In queries about income items there is very little item nonresponse about whether the household has income from some particular source. There is, however, item nonresponse about the amount of income. The HRS uses unfolding brackets to reduce the harm from item nonresponse. An unfolding bracket sequence proceeds as follows in response to the answer of "don't know” or "refuse" as to amount.

“Would it be less than $\$ 2000$, more than $\$ 2000$ or what?”

If the response is more than $\$ 2000$, a follow-up query is

“Would it be less than $\$ 5000$, more than $\$ 5000$ or what?"

In this way the income item is bracketed into one of several brackets. For example, interest from checking, saving or money market accounts is placed into one of four brackets beginning at 0$\$ 1000$ and ending at \$5,000 or more. A major strength of brackets, which is illustrated in the following graph, is that values can be imputed into the tails of the income distribution, which, because covariates do not explain a lot of the variation in income, is otherwise difficult. This is an

important issue for poverty measurement because incorrectly imputing income toward the middle of the distribution will often lift the household out of poverty. 


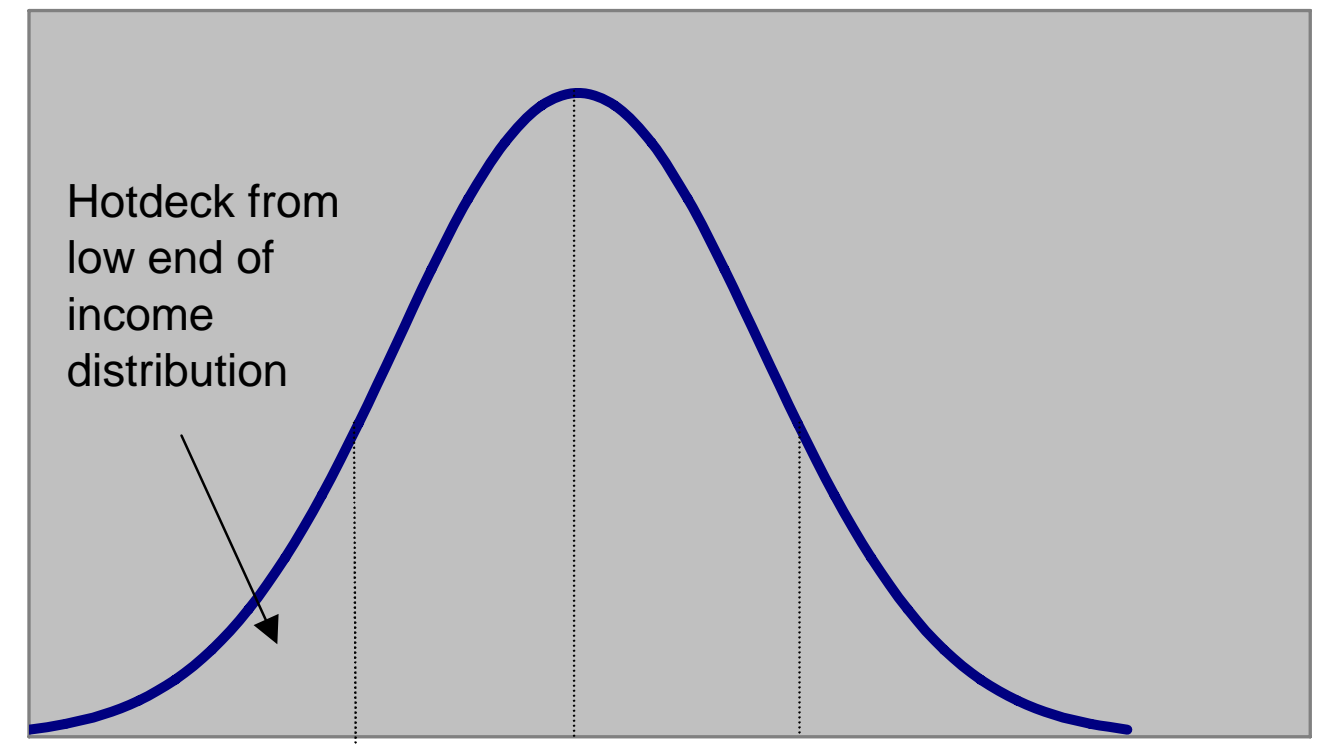

A second innovation in the HRS was the integration of income and asset questions (Hurd, Juster and Smith, 2003). In HRS waves 1 and 2 (1992 and 1994) the HRS financial respondent was asked about income in an income module. Then in a later separate module, he or she was asked about asset values. In HRS wave 3(1996), these modules were combined into an income and asset module. For example, with respect to stock ownership the following was asked:

- Do you (or your [husband/wife/partner]) have any shares of stock or stock mutual funds?
( ) Yes;
( ) No;
( ) Don't know
( ) Refuse

- If you sold all those and paid off anything you owed on them, about how much would you have? \$ (Amount).

- Do these stocks or mutual funds pay any dividends or interest?
( ) Yes;
( ) No;
( ) Don’t know
( ) Refuse

- About how much did you receive last \{TIME PERIOD \}rom that?

This sequence was repeated for

- Corporate, municipal, government or foreign bonds, or bond funds 
- Checking or savings accounts or money market funds

- Money in CDs, Government Savings Bonds, or Treasury Bills

Linking income from assets to asset values substantially increased income from assets between HRS wave 2 and HRS wave 3, especially for these four financial assets, as is illustrated by the following summary of findings:

- Mean interest and dividends more than doubled

- Wave 2: $81 \%$ had at least one of the four financial assets

o $35 \%$ of owners had some interest or dividend income

- Wave 3: $81 \%$ had at least one of the four financial assets

o $76 \%$ of owners had some interest or dividend income

Figures 1 and 2, which are taken from Hurd, Juster and Smith (2003), give some details of the increase in income from four financial assets between HRS waves 2 and 3, conditioning on the value of the assets. Thus among those with assets in the range $\$ 2,500$ to $\$ 10,000$, about $75 \%$ had no income from those assets in wave 2 but only $25 \%$ had no income from those assets in wave 3. Among those who had $\$ 10,000$ to $\$ 50,000$ in those assets only $5 \%$ had income in the range $\$ 250$ $\$ 1000$ in wave 2 whereas 30\% had income in that range in wave 3. Similar increases in income from assets were found throughout range of assets.

Under-reporting of income from assets could affect reported income of even those with incomes near the poverty line such as elderly widows. They may have little income beyond Social Security but may own some assets: with under-reporting of asset income the income of the widow might be below the poverty threshold, but with accurate reporting her income may be above it.

In summary we expect that the HRS innovations in the measurement of income could affect measured poverty status as compared with the CPS in at least two ways: Bracketing should increase measured poverty, but a better measure of income from assets should reduce measured poverty. The overall effect is an empirical matter, but it is likely to vary by age. For example, elderly widows may well have some assets so that an accurate measure of the income from those assets would cause them not to be classified into poverty. 


\subsection{Estimates of Income-based Poverty Rates in the HRS and the Effect of Imputations}

In the HRS with the bracket information we can bound the poverty rate so that it does not depend on imputations. We first assume that income is at the lower boundary of the bracket and then ask how many would not be in poverty were income at that low level. Then we assume that income is at the maximum in the bracket and ask how many would still be in poverty at that high income level. Thus the poverty rate is bounded. Then we impute income to non-core HRS household members who were bracketed using nearest neighbor conditional on a number of covariates. ${ }^{4}$ Table 3 shows the classifications and resulting poverty rates for the HRS households aged 55 or over as measured in HRS wave 6 in 2002. Among the 16,137 people aged 55 or over, 13,940 were in households where income of non-core members was completely reported. Of that group, 1,359 were in poverty for an unweighted poverty rate of about $9.7 \%$. The HRS over samples groups who have higher than average poverty rates, and so the weighted poverty rate is lower at $9.1 \%$.

Even in households where there is some missing data on the income of non-core HRS household members, the income that is reported may be enough to lift the household out of poverty. That was the case for 1,493 households. When assigning income of non-core household members to the lower boundary of the bracket, we found that 152 households would not be in poverty and that when assigning income of non-core household members to the upper boundary of the bracket 37 households would be in poverty. By these methods 15,622 households could be given a poverty status without imputing income of the non-core household members. Their unweighted poverty rate is $8.9 \%$ and their weighted poverty rates is $8.4 \%$.

The remaining 515 households cannot be classified without imputation; but we can find the sensitivity of the poverty rate to the imputations by first assuming they are all in poverty and then by assuming that none is in poverty. These assumptions result in an unweighted poverty range of $8.7 \%$ to $11.8 \%$ and a weighted range of $8.2 \%$ to $10.8 \%$. The last line of the table shows the poverty rate when we impute the missing income of non-core household members using bracket

\footnotetext{
${ }^{4}$ We use nearest neighbor imputation within bracket separately for singles and for couples because singles tend to be elderly living with their middle aged children and couples tend to be younger living with their young children or their elderly parent. Covariates are: age, race, sex, number of household residents, any household resident less than age 18, income of the core HRS respondents, and self-rated health of the core HRS respondents.
} 
information. We note that even with bracket information the unweighted and weighted poverty rates based on imputations (when necessary) are close to the minimum rate.

In 2002 the reference year for HRS income was 2001, so our comparisons with the CPS will be for 2001. Figure 3 shows by age band the HRS maximum poverty rate, the imputed poverty rate and the minimum poverty rate, and the CPS poverty rate. The HRS minimum and maximum bound the CPS rate. The imputed poverty rate has the same age pattern as the CPS rate, increasing from the first age band to the second, then decreasing, and reaching a maximum among those 75 or over. The most notable difference is that the HRS rate is lower than the CPS rate by 1.4 percentage points and 1.1 percentage points in the two highest age bands respectively. These are ages when asset income is relatively more important than earnings. We have discussed why the HRS asset income measure is likely to be superior to the CPS income measure.

Because of the difficulties of reporting income for other household members in complex households, and of assigning the "age" of the household a better comparison between the HRS and the CPS can be made by focusing on unrelated individuals alone. These are all single persons and so both in the HRS and the CPS they all report their own income. Figures 4, 5 and 6 show poverty rates of such persons. With few exceptions the HRS rates are lower than the CPS rates, and in some cases substantially lower. Of particular interest from a policy point of view is the poverty rate of older unrelated females because they are quite numerous and exhibit above average poverty rates in official statistics. They are mostly widows and represent the especially long-lived survivors of a formerly couple household. According to the HRS, the poverty rate of females aged 75 or over is about four percentage points lower than according to the CPS.

Figure 7 shows poverty rates of people who live in "married” households; that is, the reference person is married in the case of the CPS and the respondent is married in the case of the HRS. Because of scaling, the differences are large in relative terms, but in absolute terms they are not: the largest difference is about one percentage point when the reference person is 65-74.

\section{Consumption-based poverty rates in the HRS}

Consumption-based poverty rates differ from pre-tax income based poverty rates because they take into account saving or dissaving, income-in-kind, the consumption of durables, and the consumption of housing services. They implicitly account for taxes because in the long-run people 
cannot consume more than their after-tax income. Even in the medium-run, consumption flows should be approximately equal to after-tax spending flows provided there is no substantial saving or dissaving.

The difference between income-based and consumption based poverty rates is likely to vary with age and therefore has implications for age-related welfare judgments. Thus,

- Tax rates decline with age

- There is dissaving at old age

- Consumption in kind is likely more important at older age because of Medicare

- Older households may depreciate their durables more thoroughly so that they would still have a flow of consumption even though expenditures are null;

- Ownership of housing declines with age albeit slowly

We will estimate consumption-based poverty measures in the HRS using data from the HRS core and from the Consumption and Activities Mail Survey (CAMS).

\subsection{Consumption and Activities Mail Survey}

In October, 2001, CAMS wave 1 was mailed to 5,000 households selected at random from households that participated in HRS 2000. In households with couples it was sent to one of the two spouses at random. The fact that the sample was drawn from the HRS 2000 population allows

linking the spending data to the vast amount of information collected in prior waves in the core survey on the same individuals and households.

CAMS wave 1 consists of three parts. In Part A, the respondent is asked about the amount of time spent in each of 32 activities such as time spent watching TV or time spent preparing meals. Part B collects information on actual spending in each of 32 categories, as well as anticipated and recollected spending change at retirement (Hurd and Rohwedder, 2003). Part C asks about prescription drugs and current labor force status.

The instructions requested that for Part B the person most knowledgeable about the topics be involved in answering the questions. The addressee answered Part B in 88\% of households, possibly with the assistance of the spouse; $5 \%$ of the cases report explicitly that the spouse answered the 
questions; $2 \%$ had their children or children-in-law of the addressee help out in answering the questions, and the remaining $5 \%$ was a mix of miscellaneous responses including nonresponse.

Of course CAMS could not ask about spending in as many categories as the CEX, which in the recall component of the survey asks about approximately 260 categories. The design strategy adopted for CAMS was to choose spending categories starting from the CEX aggregate categories that are produced in CEX publications, so as to have direct comparability with the CEX. However, to reduce the burden to respondents the categories had to be aggregated further. The final questionnaire collected information on 6 big-ticket items (automobile; refrigerator; washer or dryer; dishwasher; television; computer) and on 26 non-durable spending categories.

The reference period for the big-ticket items is "last 12 months," and for the non-durables it varied: the respondent could choose the reference period between "amount spent monthly" and "amount spent yearly" for regularly occurring expenditures like mortgage, rent, utilities, insurance, property taxes where there is little or no variation in amounts, and "amount spent last week," " amount spent last month," and "amount spent in last 12 months" for all other categories. For all non-durable categories there was a box to tick if "no money spent on this in last 12 months." The questionnaire had no explicit provision for "don't know" or "refuse” so as not to invite item nonresponse.

Of the 5,000 mailed-out questionnaires there were 3,866 returned questionnaires giving a unit response rate of 77.3 percent.

\subsubsection{Unit non-response in CAMS}

There were lower response rates among households with certain characteristics. Table 4 shows the marginal reduction in participation in CAMS from a logistic estimation of the probability of participation on a number of household and personal characteristics. Those less than 60 were 7 percentage points less likely to participate than those aged 60-79, and those 80 or over were 10 percentage points less likely. There was no significant or substantial variation by education, income or wealth. Because of differential unit nonresponse, we use weights when calculating population averages. 


\subsubsection{Categories of spending and item response rates}

Table 5 shows the spending categories and the rate of item response. Item response in CAMS is much higher than it is for typical financial variables such as the components of wealth or income where it can be as low as 60\%. A consequence of the high response rates is that $54 \%$ of households in CAMS wave 1 were complete reporters over all 32 categories of spending. An additional 26\% had just one or two nonresponse items. Ninety percent of the sample were complete reporters of 26 categories or more. Furthermore, in the spending categories with the highest rate of nonresponse, we have information from the HRS core that we can use for imputation. For example, rent has almost the highest rate of nonresponse. However, we have responses in the HRS about homeownership which we can use with considerable confidence to impute rent. Of the 512 who were nonrespondents to the rent query, 427 owned a home in HRS 2000. We believe we can confidently impute zero rent to these households. Similarly among nonrespondents to the question about homeowners insurance and who owned a home with mortgage in 2000, 66\% reported that their insurance was included in their mortgage payment. Apparently they did not respond in CAMS because they had already included that amount in the mortgage report.

Using the HRS core data we imputed (mostly zeros) for some households in up to 18 spending categories. The number of households imputed in a particular category ranged from just a few to 470. Based on these and similar imputations that use HRS core data to provide householdlevel information, 63.5\% of CAMS respondents are complete reporters over all 32 categories of spending.

Because of the small amount of item nonresponse that remains we used simple imputation methods from the mean of the reported amount. See Hurd and Rohwedder (2005) for further details.

\subsubsection{CAMS-CEX comparisons}

The Consumer Expenditure Survey (CEX) is the survey in the U.S. that collects the most detailed and comprehensive information on total spending, so a natural validation exercise for the spending data in CAMS is to compare them to the CEX. Table 6 has comparisons between

spending in CAMS and spending in the CEX. In every age band but one spending in CAMS is 
higher than in the CEX and particularly at advanced old age it is substantially higher. This difference is likely to be partly due to the problem of the reference person: the CEX uses that concept just as the CPS uses it whereas the HRS does not as we discussed earlier. A symptom is that income as measured in the HRS is substantially higher than income as measured in the CEX probably reflecting a difference in the populations represented. Other differences are likely to be due to the survey instrument. These topics are beyond the scope of this paper to investigate.

\subsection{Taxes}

We will want to compare consumption with after-tax income. So we used the NBER TAXSIM model to calculate Federal, state and Social Security taxes for each household in our sample (Hurd and Rohwedder, 2005). A limitation is that we can only perform the calculation for the HRS singles and couples in a reliable way. Furthermore, it is very likely that other members of the household would file separate tax forms. We therefore restrict our analyses in the remainder of the paper either to single persons living alone or to married couples living alone.

\subsection{Validation of Consumption Data}

Figure 8 shows pre-tax and after-tax income and spending of the CAMS sample. ${ }^{5}$ Whereas pre-tax income declines sharply with age, after-tax income declines much more slowly. Spending declines more slowly still reflecting the fact that households in their 50s and early 60s save and households above about 75 dissave: spending becomes greater than after-tax income in the age band 75-84.

Figure 9 shows saving rates out of after-tax income by marital status. Except for some noisy variation among singles the saving rates are consistent with the following observation: Although the rate of saving declines monotonically with age, couples always save until advanced old age; singles do not save at any age, and dissave substantially at advanced old age. These results are consistent with a life-cycle model in which couples preserve capital so that the surviving spouse will have resources to finance spending to advanced old age.

These saving rates are found by comparing after-tax income with spending both of which are measured with error. To validate the average levels we will compare them with panel wealth

\footnotetext{
${ }^{5}$ This figure and Figure 9 exclude composite households because of our inability to calculate taxes in them.
} 
change. Except for capital gains, over long periods of time the change in wealth should be equal to the inflow or outflow of resources into wealth accounts. Because of capital gains we will not be able to make a quantitative comparison; rather we would like to see whether the age-pattern in saving rates is found in the wealth change and whether the pattern by marital status is also found. For this comparison we use panel wealth change between HRS waves 3 to 4,4 to 5 and 5 to 6 , which cover the years (approximately) 1996-1998, 1998-2000, and 2000-2002. ${ }^{6}$ Our method is to calculate changes in median or mean wealth in each of the three panel comparisons by age band and by marital status. To smooth the rather violent changes in the stock market over this period we average the three changes. These results are shown in Figures 10 and 11. We see that as measured by changes in median wealth the broad pattern of saving by age is found in changes in wealth: among couples prior to retirement median real wealth increased by about $5 \%$ every two years. At older ages there was little change until advanced old age. For singles in the youngest age band, median wealth increased by about $2 \%$ over two years. It was approximately constant at older ages until advanced old age. The means show a qualitatively similar pattern but with larger changes in the first age band reflecting the influence of large wealth holders. We view these wealth changes as supporting the saving rates that come from the difference between after-tax income and spending.

\subsection{From Spending to Consumption}

CAMS has spending on durables, but we want consumption of services from durables. For five of our big ticket items (excluding automobile purchases) our general strategy is to estimate in CAMS the probability of a purchase and the expected value conditional on a purchase as functions of important covariates such as income, wealth, age and marital status. Then we impute an annual purchase amount which, in equilibrium, will be equal to the annual consumption with straight line depreciation. In particular we make the following assumptions and calculations:

- Straight-line depreciation

- Average annual consumption = average annual depreciation

- Logit for probability of annual purchase. Covariates are age, income, marital status, people in household and number of household residents.

- Spending conditional on purchase: same covariates

\footnotetext{
${ }^{6}$ AHEAD was fielded in late 1995 and again in 1998 and covered those 72 or over in 1995 . We combine them with HRS cohorts who were interviewed beginning in March, 1996 and again in 1998 for the waves 3 to 4 calculation.
} 
- Predicted average annual consumption on six big-ticket items = (probability of purchase $) \times($ expected amount given purchase $)$

From these estimations we find mean consumption of five big ticket items to be $\$ 271$ per year with a range $\$ 67$ to $\$ 2,581$.

Because we have the value of automobiles and other vehicles used for transportation in the HRS in 2000 and 2002, we calculate the flow of services from the actual values. This calculation will more accurately estimate the flow of services for low income households. We make these assumptions and calculations:

- The value of transportation (almost all automobiles) is from the HRS core

- User cost is the sum of interest on the value, depreciation on a 12-year schedule and observed maintenance costs from CAMS.

We find that the mean flow of services is $\$ 2,803$ per year with a range of $\$ 0$ to $\$ 39,500$.

We follow a similar strategy to estimate the flow of consumption services from owneroccupied housing by estimating a rental equivalent: what the housing unit would rent for in a competitive market in equilibrium. In particular we make the following assumptions and calculations.

- The interest cost is the value of housing multiplied by the prevailing interest rate. We use the observed value from the HRS core and assume an interest rate of 7.16\%, which was the average 30 year mortgage interest rate in 2001.

- Property taxes (observed in CAMS)

- Insurance (observed in CAMS)

- Depreciation estimated from maintenance costs (observed in CAMS) and house value: $2.14 \%$ per year (= 47 year depreciation)

The flow of housing services is the sum of these items.

One difference between spending and consumption is income-in-kind. For the older population by far the most important income-in-kind is Medicare. However, the valuation of Medicare or even out-of-pocket health care expenditures is controversial. The National Academy of Sciences panel on measuring poverty recommended excluding out-of-pocket spending from income when assessing poverty status, but the recommendation drew sharp dissent from one panel member (Citro and Michael, 1995). Furthermore, the panel's methods of treating health care spending results in large variation in poverty rates in the elderly population. For example, in 2003 
the official poverty among the elderly was $10.2 \%$ (Delaker, 2005). But the poverty rate varied between $14.0 \%$ and $17.3 \%$ when various of the panel's recommended measures were used. Thus, the method of treating health care spending can have a large effect on measured poverty. Because of the lack of agreement among researchers, we follow the method of the official poverty rate calculation and do not do place any value on Medicare or Medicaid, even though we recognize that those programs certainly have considerable value to the older population. Similarly we do not include health care consumption financed by others such as employers. While the HRS core queries about gifts and money received from others outside the household, it does not distinguish between them, so we do not include non-money gifts received from others. We do include out-of-pocket spending for health care.

Total consumption is the sum of the consumption of 26 nondurables, the consumption of services from five durables, the consumption of services from transportation (mainly automobiles), and the consumption of services from owner-occupied housing.

\subsection{Estimates of consumption-based poverty rates}

We compare the household total consumption to the official poverty thresholds to find the household's poverty status based on consumption.

Figure 12 shows by age band the poverty rate as measured by pre-tax income, and consumption. Except for the greatest age band the poverty rate is considerably higher when measured by income rather than by consumption. ${ }^{7}$ Figure 13 shows poverty rates for unrelated individuals when measured by pre-tax income, after-tax income and by consumption. Among those 55-59 the poverty rate is about 2.5 percentage points higher when measured by after-tax income rather than by pre-tax income. Even low income families pay Social Security taxes out of earnings. At older ages the difference is minor and at advanced old age the poverty rate is slightly lower on an after-tax basis. ${ }^{8}$ When measured by consumption the poverty rate is considerably lower, as much as 11.8 percentage points, than when measured by after-tax income. Among those 75 or over, which would mostly be widows, the consumption-based poverty rates is just $6.2 \%$. These rates give a very

\footnotetext{
${ }^{7}$ We cannot show after-tax poverty rates for all households because we are unable to calculate after-tax income of complex households.

${ }^{8}$ Due to low-income tax credits mostly at the state level.
} 
different impression of the prevalence of poverty as conventionally measured: for the same group that measure is $14.2 \%{ }^{9}$

Figure 14 shows poverty rates for couples who are living alone. In this type of household we can calculate taxes, so the figure has pre-tax, after-tax and consumption based poverty rates. Compared with unrelated individuals, the poverty rates of couples are very low, and at advanced old age very close to zero. This decline is likely due to differential morality as the less well-to-do households die. The pattern is consistent with the saving rates in Figure 9 and the wealth changes in Figures 10 and 11 which show that couples dissave little, if at all, as they age.

\section{Relationship between after-tax income and consumption-based definitions of poverty}

To understand the characteristics of households that are classified into poverty on the basis of income but not on the basis of consumption we first present the correspondence between these measures in Table 7. Because we do not have a good calculation of taxes in composite households we limit the sample to singles and couples who have no other residents.

About 24\% of those classified into poverty on an income basis are also classified into poverty on a consumption basis. About $52 \%$ of those classified into poverty on a consumption basis are also classified into poverty by income. Our first interest is whether there are differences in wealth that can explain the differences in poverty rates. To do that we divide those in poverty according to income into two groups: those also in poverty according to consumption and, those not in poverty according to consumption. Then we ask: What are the wealth differences between these two groups? These wealth differences are shown in Table 8. Because we need to calculate consumption and after-tax income the sample is limited to the CAMS sample of singles and marrieds who have no other residents.

The mean nonhousing wealth of those in poverty according to after-tax income and also according to consumption is $\$ 187$ whereas mean wealth of those in poverty according to after-tax income but not in poverty according to consumption is about $\$ 158$ thousand. Of course mean wealth is heavily influenced by outliers, but at the $75^{\text {th }}$ percentile the wealth difference is large. We

\footnotetext{
${ }^{9}$ Slesnik (1993) compares poverty rates based on income with those based on consumption using the CEX. His measure of consumption is expenditures and finds about a five percentage point difference between the income-based measure and the consumption-based measure. Our results for unrelated individuals show a greater difference but for the entire sample a smaller difference.
} 
conclude that nonhousing wealth can be used by some people to finance more consumption than after-tax income.

Next we study a number of factors jointly: home ownership, non-housing wealth, age, education and marital status. We estimate a logistic model for poverty status as measured by consumption over the sample that is in poverty as measured by after-tax income. The sample is the CAMS sample of singles and couples living alone. The number of observations is slightly different because Table 8 has weighted observations whereas the logistic estimation is based on an unweighted sample

In Table 9, being single reduces the odds of not being in poverty according to consumption by a factor of 0.31 ; that is, a single person is about three times more likely to be in poverty by a consumption definition relative to a married person. This factor is almost offset by an increase in the odds of being out of poverty for females, so that an elderly widow is not substantially more likely than a married person to be in poverty. ${ }^{10}$ Being a home owner increases the odds of not being in poverty according to the consumption definition with relative risk of 1.83. Those in highest nonhousing wealth quartile are six times as likely to be not in poverty as those in the lowest quartile. There is little relation to age.

\section{Conclusions}

We have found that the HRS is suitable for assessing poverty in the elderly population. It matches up quite closely with CPS overall, but it has lower rates for some types of households, particularly single households. Because of innovations in measurement in the HRS, it may be that the HRS measure is more reliable but that conclusion will have to await further research. However, for some types of households such as those where elderly persons live with their children, the CPS is likely more reliable.

The finding that the HRS poverty measures compares fairly closely to the CPS measure is valuable because the HRS is the only data set where income, wealth and consumption are available. This permits the study of internally consistent relationships such as dissaving as measured by wealth change and dissaving as evidenced by income minus consumption. Furthermore, the HRS

\footnotetext{
${ }^{10}$ Of course, this statement is the result of holding constant the other covariates. In the population couples are more likely to be home owners and to have more education.
} 
has many years of panel data on a very wide range of personal and household characteristics that can be used to understand poverty and poverty transitions.

We found that consumption-based poverty rates are considerably lower than income based poverty rates, especially for single people. The difference in poverty status when moving from an income-based measure to a consumption-based measure is not only due to home-ownership and the derived housing services. Assets play an important role, in particular among the retired. 


\section{References}

Bauman, K. (1998), “Direct Measures of Poverty as Indicators of Economic Need: Evidence from the Survey of Income and Program Participation,” Technical Working Paper 30, U.S. Census Bureau, Population Division, Washington, DC.

Bauman, K. (2003), "Extended Measures of Well-Being: Living Conditions in the United States: 1998,” Current Population Reports P70-87, Washington, DC, U.S. Government Printing Office.

Bradshaw, J. (2001), “Methodologies to measure poverty: more than one is best!” International Symposium Poverty: Concepts and Methodologies, Mexico City.

Citro, Constance and Robert Michael (1995), Measuring Poverty: A New Approach, Washington, D.C.: National Academy Press

Cutler, D. and Katz, L. (1991), “Macroeconomic Performance and the Disadvantaged,” Brookings Papers on Economic Activity, 2.

Delaker, Joe (2005), “Alternative Poverty Estimates in the United States: 2003,” U.S. Census Bureau, Current Population Reports, Consumer Income, P60-227

Federman, M., Garner, T., Short, K., Cutter IV, W., Kiely, J., Levine, D., McGough, D. and McMillen, M. (1996), “What Does It Mean to Be Poor in America?” Monthly Labor Review, 119(5), 3-17.

Fernandez-Villaverde, J. and Krueger, D. (2002), “Consumption Over the Life Cycle: Some Facts from Consumer Expenditure Survey Data,” NBER Working Paper 9382.

Garner, T., Janini, G., Passero, W., Paszkiewicz, L. and Vendemia, M. (2003), “The Consumer Expenditure Survey in Comparison: Focus on Personal Consumption Expenditures,” Washington, DC: US Department of Labor - Bureau of Labor Statistics. 
Garner, T. and Short, K. (2001), “Owner-Occupied Shelter in Experimental Poverty Measures,” Paper prepared for the Annual Meeting of the Southern Economics Association Conference, Tampa, Florida, November 2001.

Garner, T. and Short, K. (2005), “Economic Well-Being Based on Income, Consumer Expenditures and Personal Assessments of Needs,” Working Paper 381, U.S. Bureau of Labor Statistics, Washington, DC.

Hurd, M. D., Juster, F. T. and Smith, J. P. (2003), “Enhancing the Quality of Data on Income: Recent Innovations from the HRS,” Journal of Human Resources, 38 (3), pp. 758-772.

Hurd, M. D., and Rohwedder, S. (2003), “The Consumption and Activities Mail Survey,” typescript, RAND.

Hurd, M. D. and Rohwedder, S. (2005), “The Consumption and Activities Mail Survey: Description, Data Quality, and First Results on Life-Cycle Spending and Saving,” typescript, RAND, 2005

Johnson, D., Smeeding, T. and Torrey, B. (2005), “Economic Inequality Through the Prisms of Income and Consumption,” Monthly Labor Review, April, pp. 11-24.

Jorgenson, D. (1998) “Did We Lose the War on Poverty?” Journal of Economic Perspectives, 12: 1, pp. 79-96.

Jorgenson, D. and D. Slesnick (1987) “Aggregate Consumer Behavior and Household Equivalence Scales,” Journal of Business and Economic Statistics, 5(2): 219-232.

Mayer, S. and C. Jencks (1993), "Recent Trends in Economic Inequality in the United States: Income versus Expenditures versus Material Well-Being,” in D.B. Papadimitriou and E. N. 
Wolff (eds.), Poverty and Prosperity in the USA in the Late Twentieth Century, St. Martin's Press, New York.

McGregor, Patrick and V. K. Barooah (1992), “Is Low Spending or Low Income a Better Indicator of Whether or Not a Household is Poor: Some Results From the 1985 Family Expenditure Survey,” Journal of Social Policy, 21:1, 53-69.

Meyer, B.D. and J.X. Sullivan (2003), "Measuring the Well-Being of the Poor Using Income and Consumption,” NBER Working Paper, No. 9760.

Rogers, J. and Gray, M. (1994), “CE Data: Quintiles of Income versus Quintiles of Outlays,” Monthly Labor Review, 118(8), pp.32-37.

Saunders, P. (1997), “Poverty, Choice and Legitimacy,” Social Policy Research Centre: Discussion Paper No 76.

Pendakur, K. (2001), “Consumption Poverty in Canada, 1969 to 1998,” Canadian Public Policy, 27:2, 125-149.

Sabelhaus, J. and Groen, J. (2000), “Can Permanent Income Theory Explain Cross-Section Consumption Patterns? Review of Economics and Statistics, 82(3):431-438.

Short, K., Shea, M., Johnson, D. and Garner, T. (1998), "Poverty-Measurement Research Using the Consumer Expenditure Survey and the Survey of Income and Program Participation,” American Economic Review, 88(2), 352- 356.

Slesnick, D. (1993), “Gaining Ground: Poverty in the Postwar United States,” Journal of Political Economy, Vol. 101:1.

Slesnick, D. (1994), “Consumption, Needs and Inequality,” International Economic Review, 35(3).

Slesnick, D. (2001), Consumption and Social Welfare, Cambridge: Cambridge University Press. 
Zaidi, M. and de Vos, K. (2001), “Trends in consumption-Based Poverty and Inequality in the European Union During the 1980s,” Journal of Population Economics, 14: pp. 367-390. 
$\underline{\text { Figure } 1}$

\section{Distribution of income from assets}

Assets 2.5k-10k

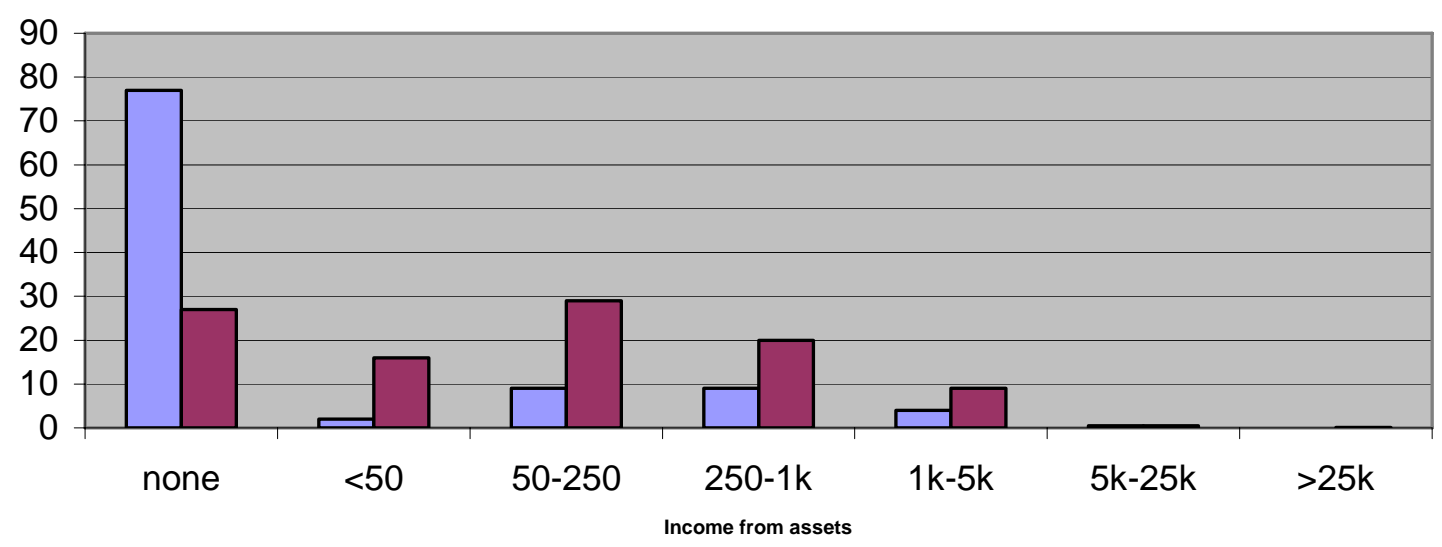

口HRS 2 口HRS 3

Source: Hurd, Juster and Smith (2003)

Figure 2

\section{Distribution of income from assets \\ Assets 10k-50k}

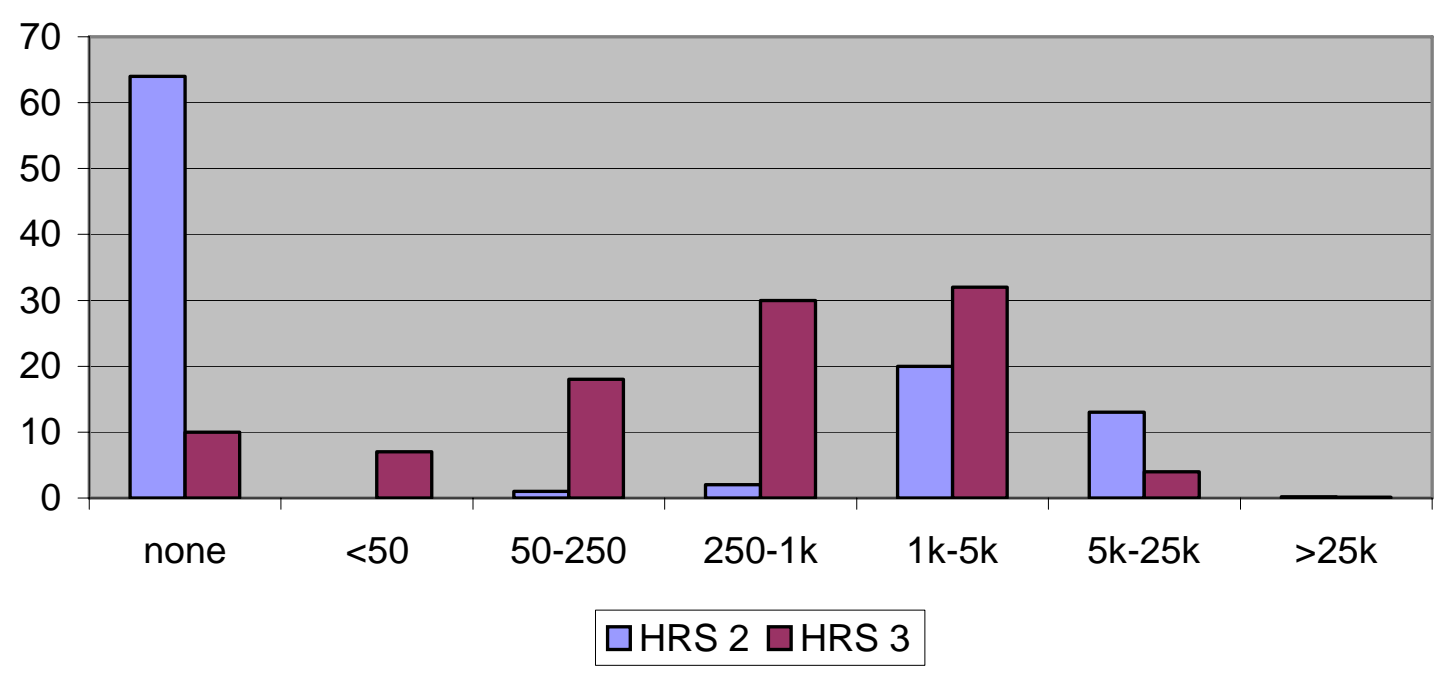

Source: Hurd, Juster and Smith (2003) 
Figure 3

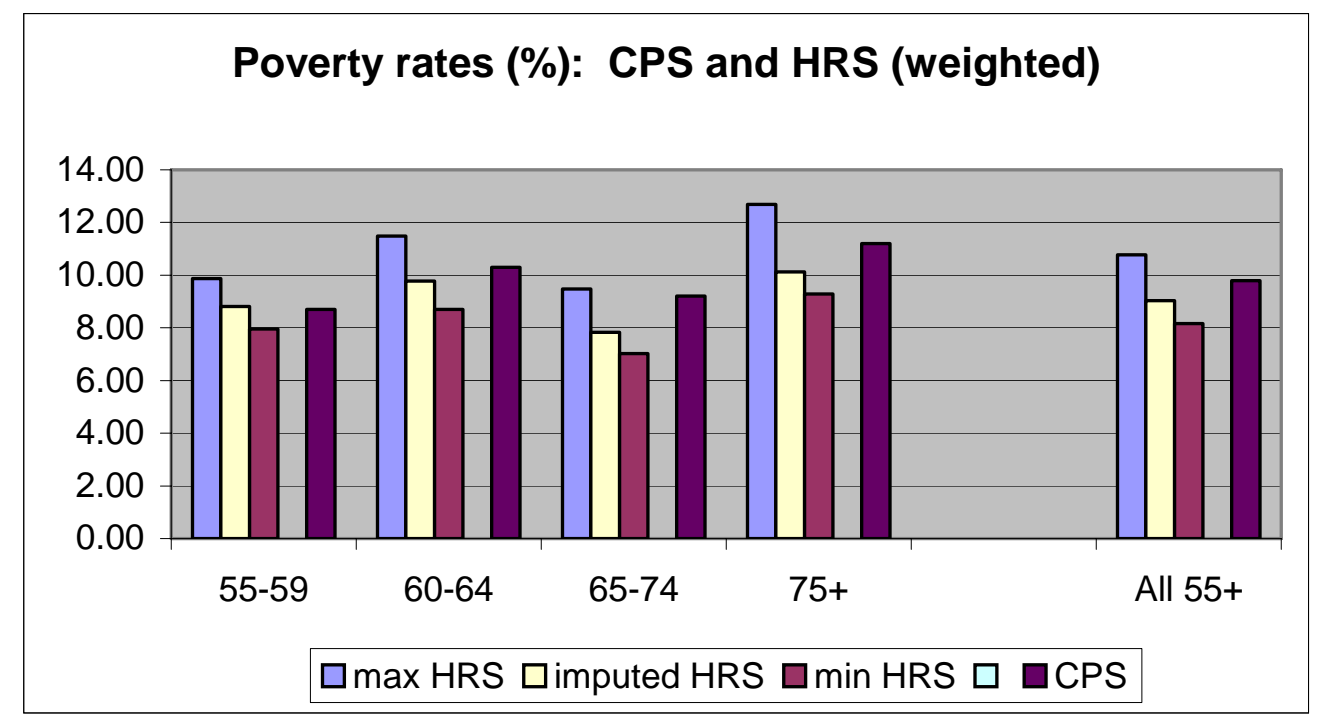

Source: Authors' calculations.

Figure 4

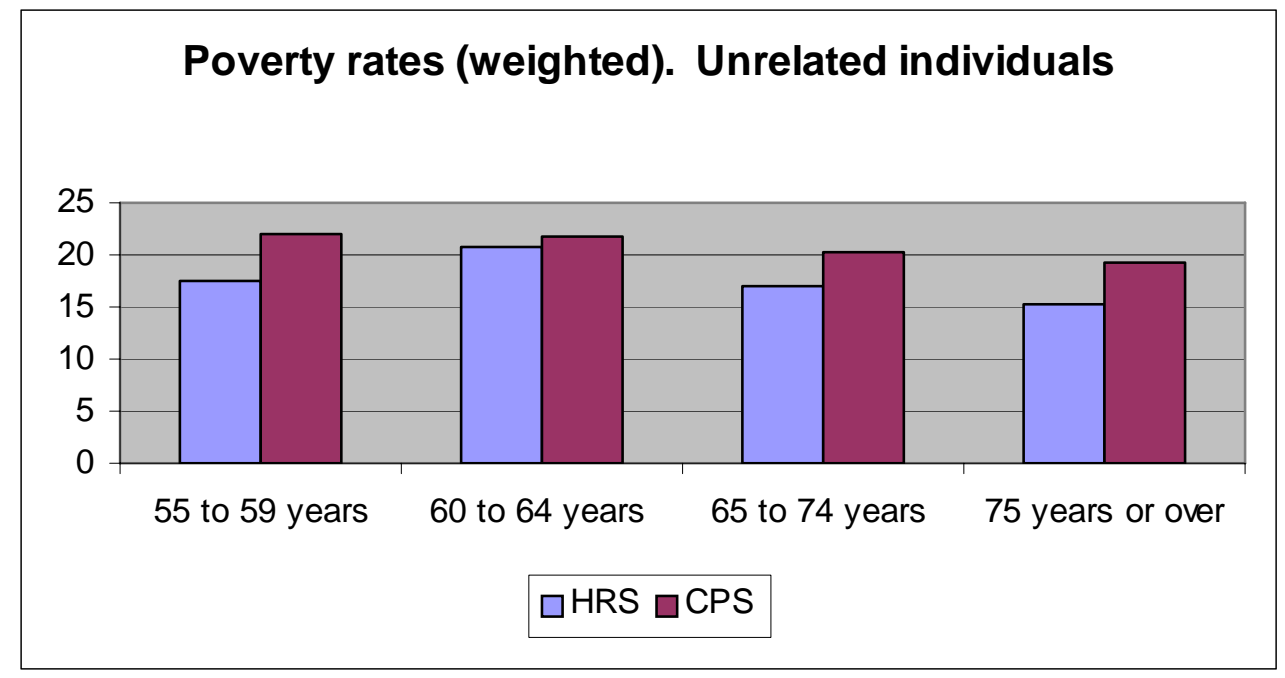

Source: Authors' calculations. 
Figure 5

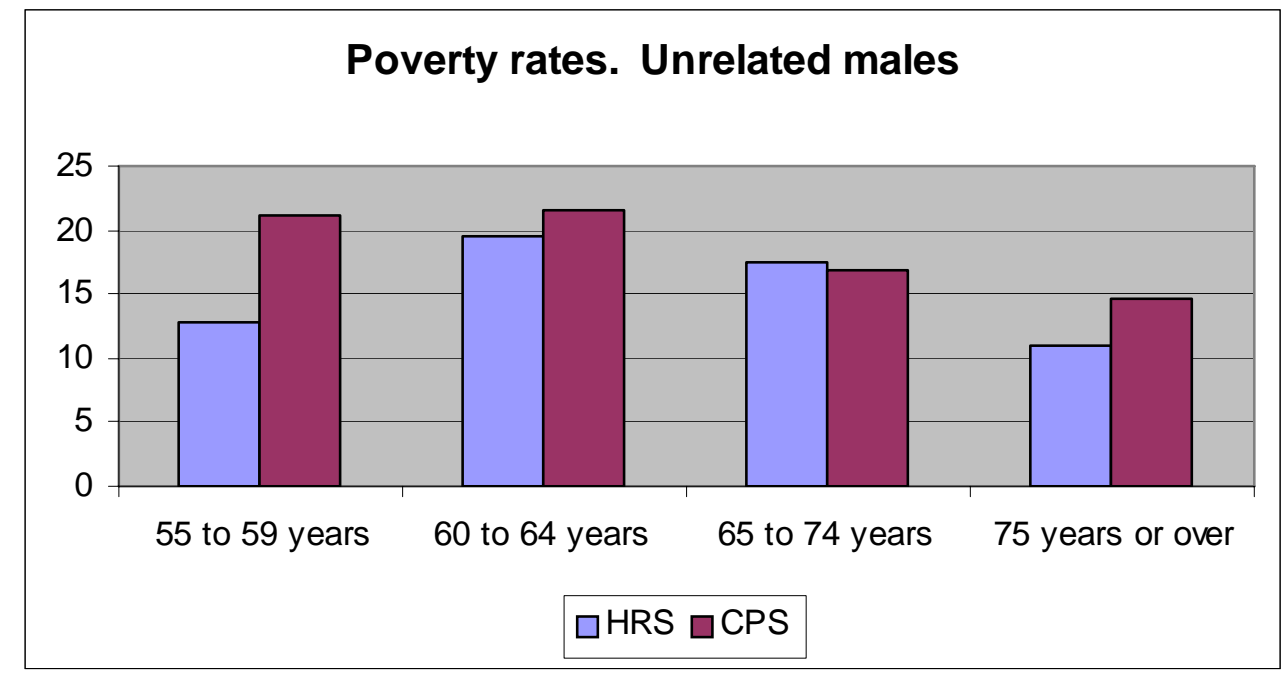

Source: Authors' calculations.

Figure 6

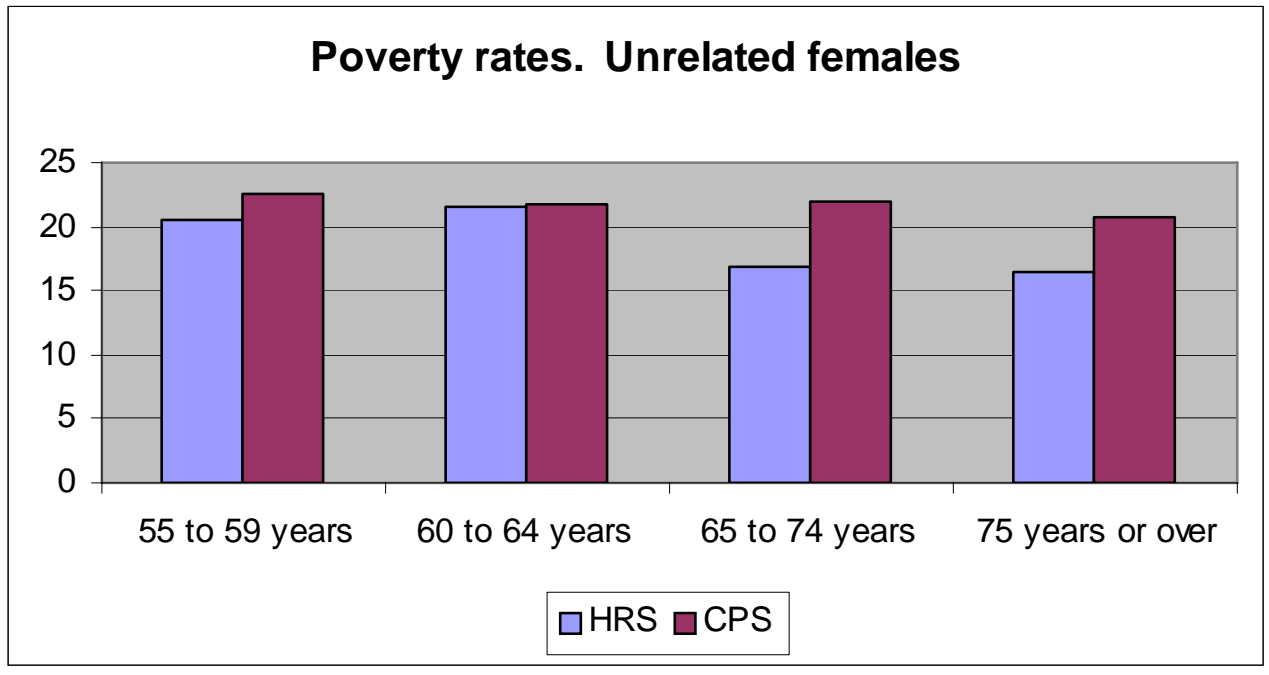

Source: Authors' calculations. 
Figure 7

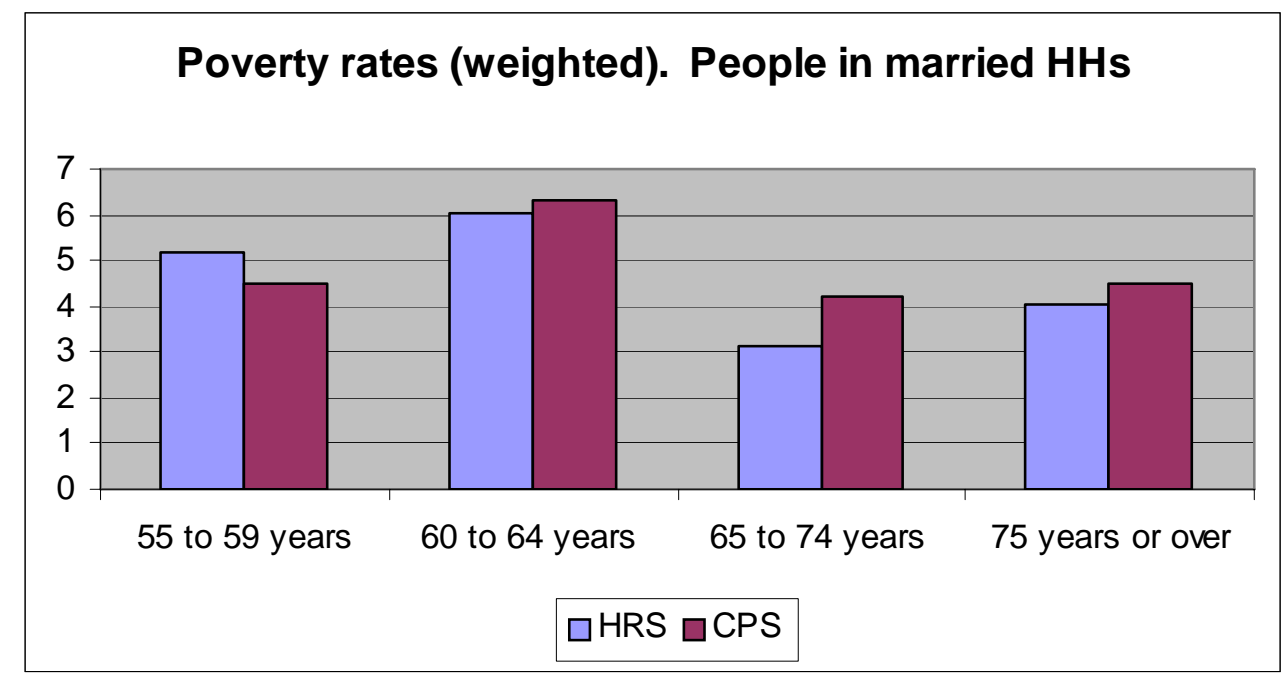

Source: Authors' calculations.

$\underline{\text { Figure } 8}$

CAMS: Gross and after tax income, and spending

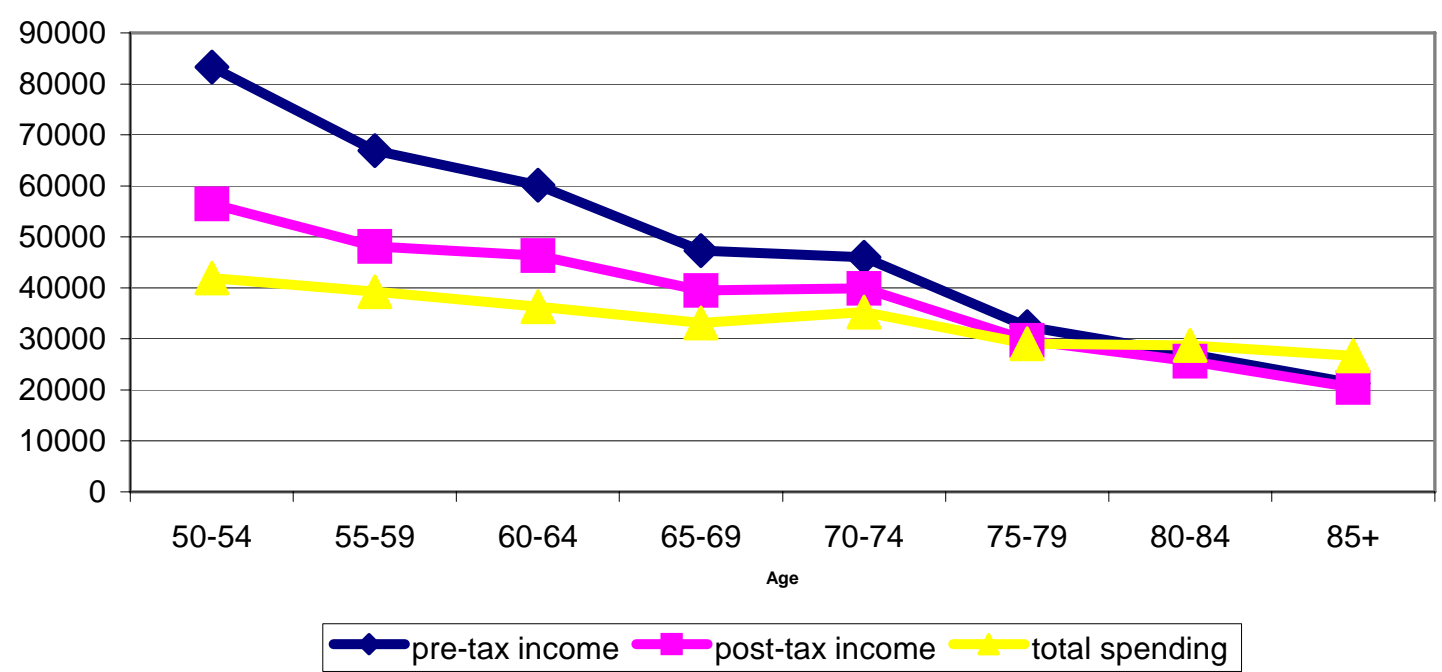

Source: Authors’ calculations. 
Figure 9

Saving rates (out of post-tax income)

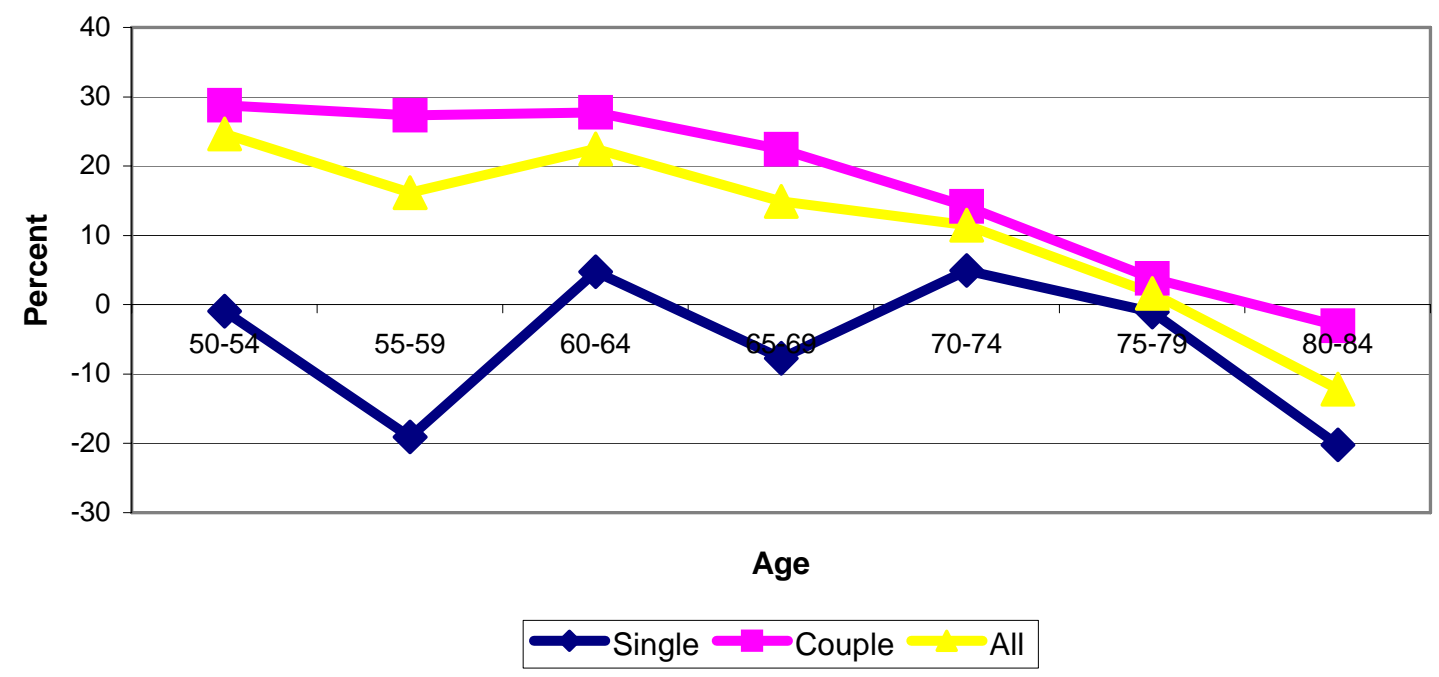

Source: Authors’ calculations.

Figure 10

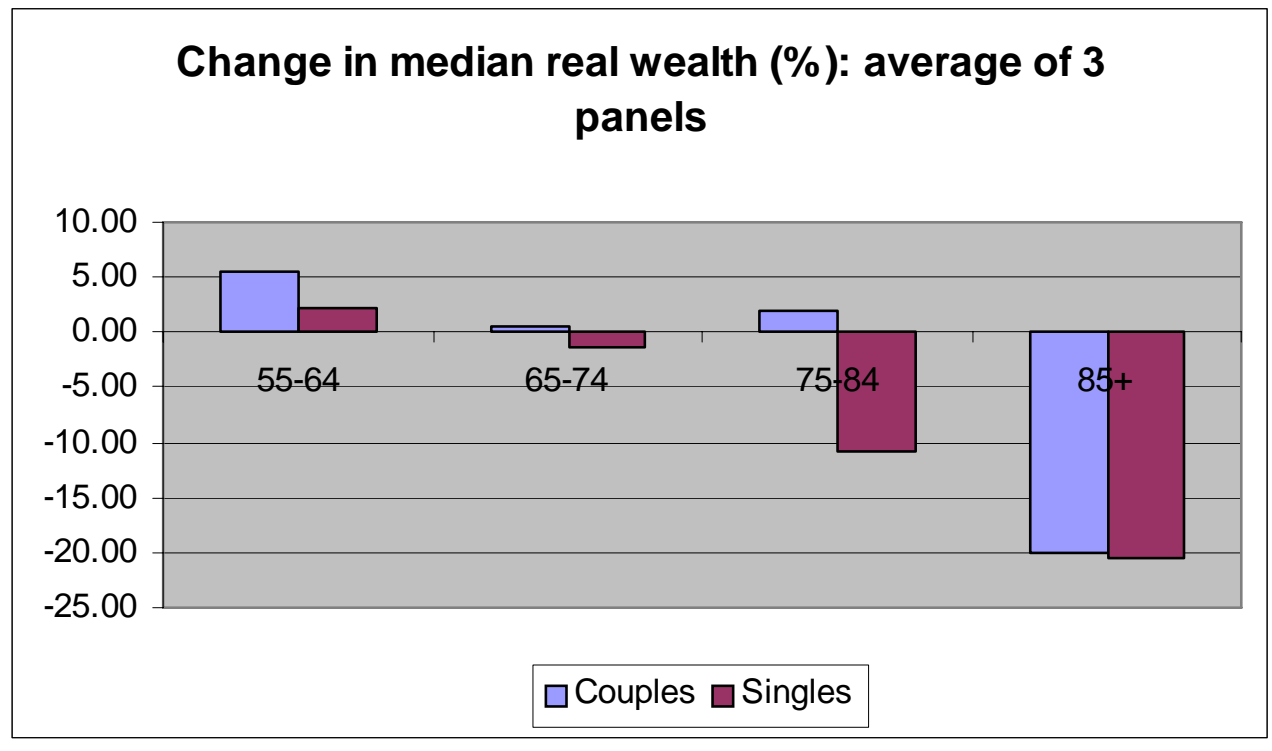

Source: Authors’ calculations. 
Figure 11

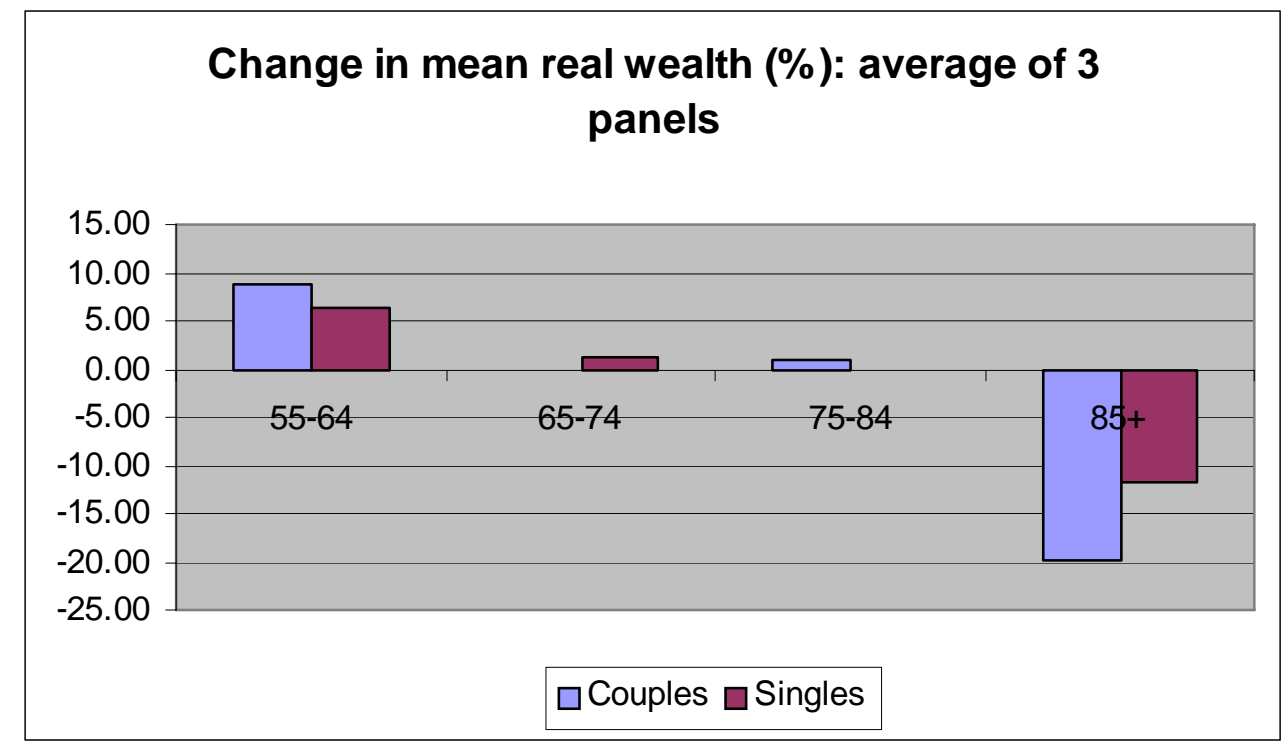

Source: Authors' calculations.

Figure 12

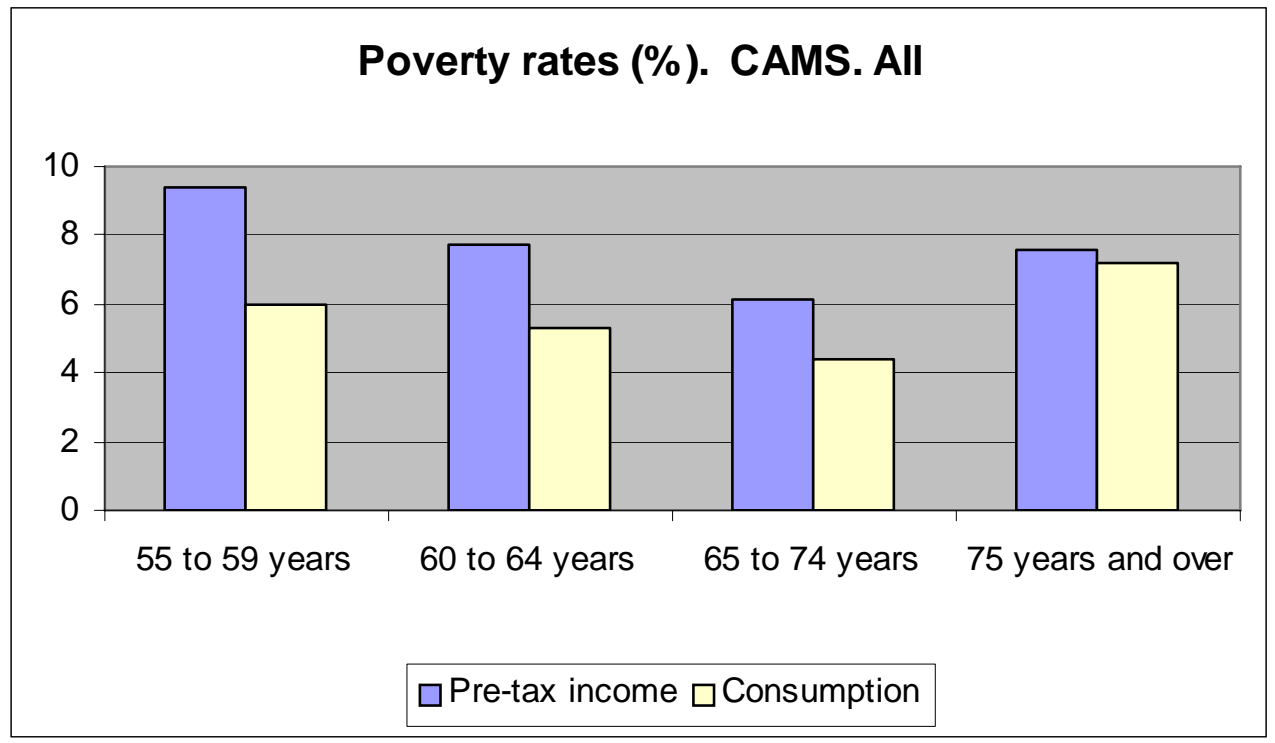

Source: Authors' calculations. 
Figure 13

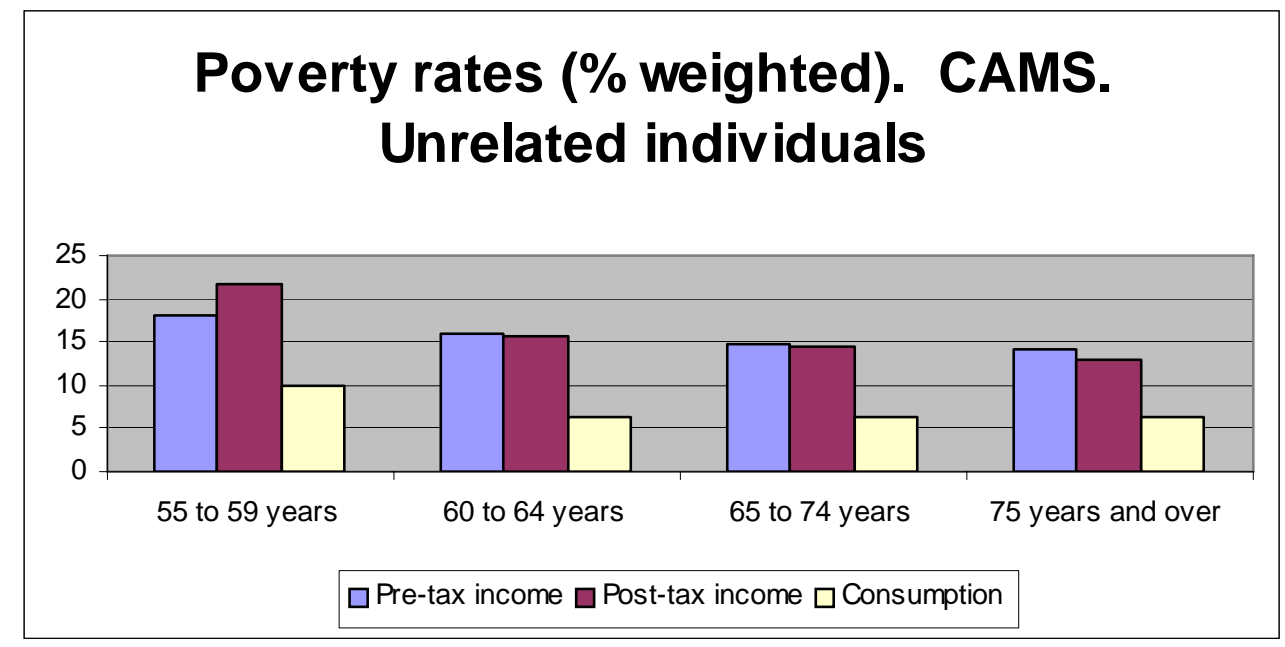

Source: Authors' calculations.

Figure 14

Poverty rates (\%). CAMS sample. People in 2-person married households

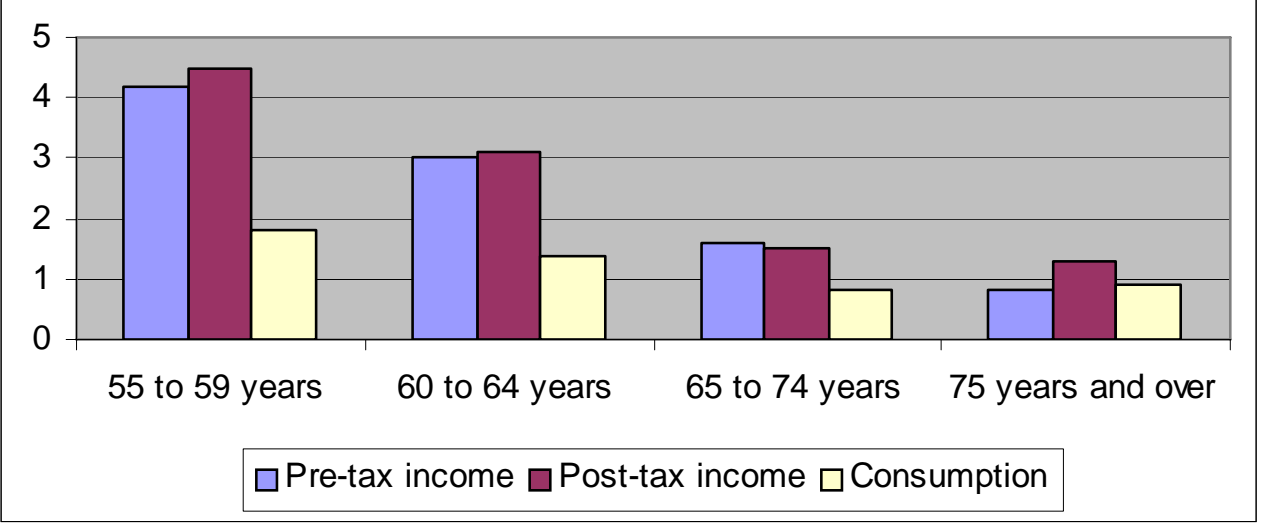

Source: Authors' calculations. 


\section{Table 1}

Poverty thresholds, 2001

\begin{tabular}{lccccc}
\hline & One person & Two persons & Three persons & Four persons & Five persons \\
\hline $\begin{array}{l}\text { Householder } \\
\text { under 65 years }\end{array}$ & 9,214 & 11,920 & & & \\
$\begin{array}{l}\text { Householder } \\
\text { 65 years and }\end{array}$ & & & & & \\
$\begin{array}{l}\text { over } \\
\text { Average }\end{array}$ & 8,494 & 10,715 & & & \\
\hline
\end{tabular}

\section{Table 2}

Components of income in the CPS

Pre-tax earnings

Net earnings from business or farm

Unemployment compensation; strike benefits

Worker's Compensation (injury or illness)

Social Security benefits

Supplemental Security Income

Public assistance or welfare

Veterans' payments

Survivor benefits: regular payments from pension, estate, trust, annuity, life insurance

Other disability payments

Pension or retirement income

Reimbursement for educational expenses

Child support payments

Alimony

Regular financial assistance from friends, relatives outside the household

Hobbies, home businesses, farms, or business interests not already covered

Unemployment compensation, severance pay, welfare, foster children care or any other money income not already covered. 


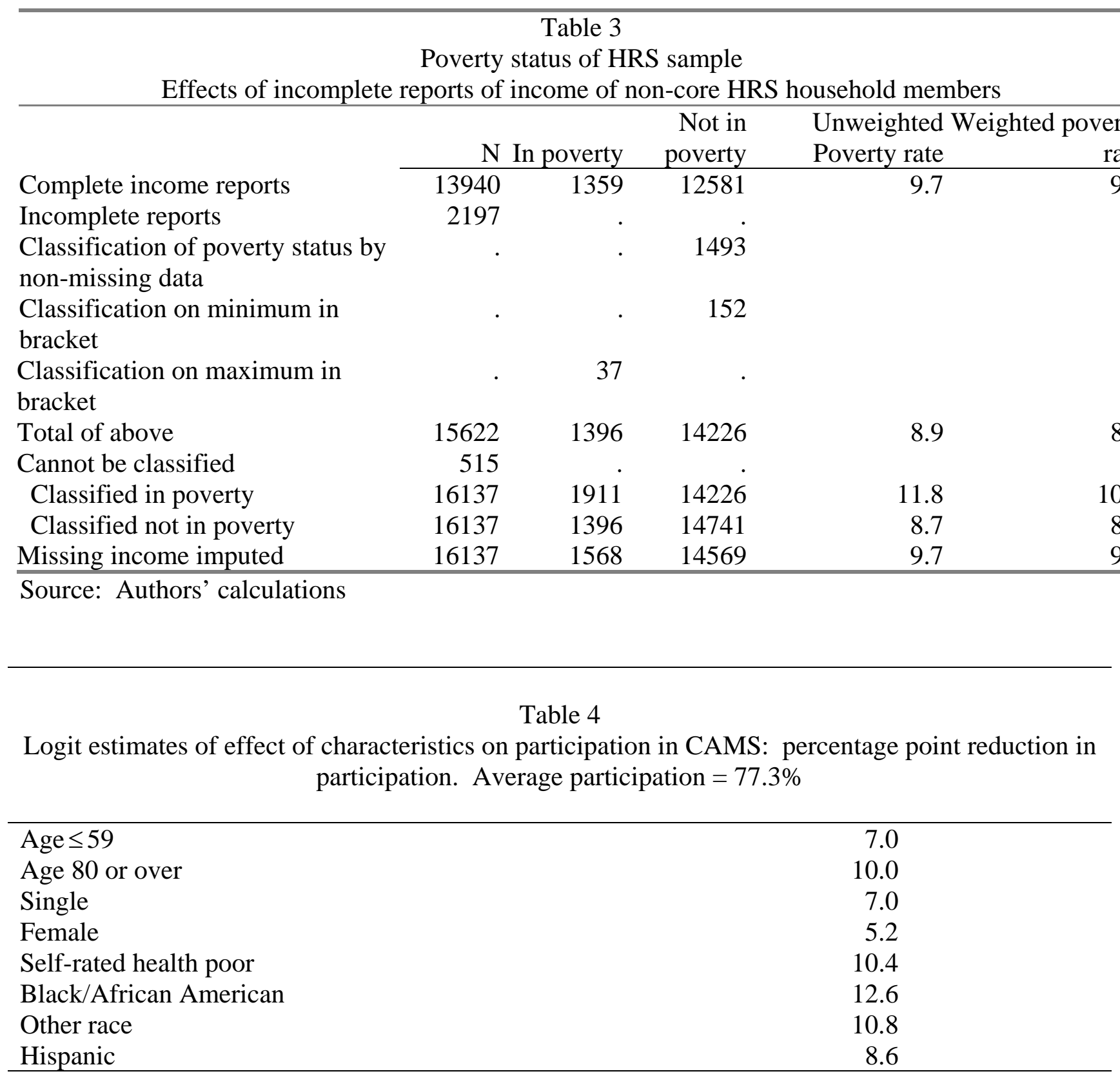

Note: Also includes income, wealth, education

Source: Hurd and Rohwedder, 2005 
Table 5

Unweighted item response rates (\%) in CAMS 2001

Big ticket item purchases

Automobile or truck

96.4

Refrigerator

96.5

Washing machine/dryer

97.8

Dishwasher

97.7

Television

97.2

Computer

97.4

Payments

Mortgage

92.2

Homeowner's or renter's insurance

88.7

Property tax

88.8

Rent

86.8

Electricity

92.4

Water

89.6

Heating fuel for the home

86.3

Telephone, cable, internet

93.9

Vehicle finance charges

86.2

Vehicle insurance

92.0

Health insurance

91.1

Spending

Housekeeping, yard supplies

93.7

Home repairs and maintenance

93.9

Food and beverages

94.7

Dining/drinking out

94.7

Clothing and apparel

94.1

Gasoline

93.4

Vehicle maintenance

93.2

(Non-)Prescription medications

94.5

Health care services

93.7

Medical Supplies

92.0

Trips and Vacations

94.7

Tickets to movies, events etc.

94.9

Hobbies

94.2

Contributions

94.4

Cash or gifts to family/friends

94.1

Source: Hurd and Rohwedder, 2005 
Table 6

Comparison of CAMS and CEX spending

(dollars in thousands)

\begin{tabular}{lccccc}
\hline & 55 or over & 65 or over & $55-64$ & $65-74$ & 75 or over \\
\cline { 2 - 6 } Spending CAMS & 35.5 & 32.7 & 39.6 & 35.5 & 29.6 \\
Spending CEX & 32.8 & 27.4 & 40.9 & 31.7 & 22.8 \\
\hline
\end{tabular}

Source: Hurd and Rohwedder, 2005

\section{Table 7}

Percent distribution of poverty status (weighted)

$\mathrm{N}=3651$

\begin{tabular}{lrrr}
\hline & \multicolumn{3}{c}{ Consumption-based definition } \\
\hline Income-based definition & No & Yes & All \\
\hline No & 92.47 & 1.37 & 93.84 \\
Yes & 4.68 & 1.48 & 6.16 \\
All & 97.15 & 2.85 & 100.00 \\
\hline
\end{tabular}

Source: Authors' calculations

Table 8

Distribution of non-housing wealth among those in poverty according to income.

$$
\mathrm{N}=226
$$

\begin{tabular}{lrrrrrr}
\hline & \multicolumn{5}{c}{ Percentile } \\
\hline Poverty status (cons. based) & Mean & 10 & 25 & 50 & 75 & 90 \\
\cline { 2 - 7 } Yes & 187 & $-1,850$ & 0 & 46 & 1,500 & 4,038 \\
No & 158,202 & 0 & 0 & 1,600 & 16,500 & 105,000 \\
\hline
\end{tabular}

Source: Authors' calculations 
Table 9

Probability of not in poverty according to consumption: logit estimation ( $\mathrm{N}=239$ in poverty according to income)

\begin{tabular}{lrr}
\hline & & P-value \\
Sex $=$ female & Odds ratio & 0.11 \\
Single & 2.01 & 0.02 \\
Home ownership & 0.31 & 0.10 \\
Less than high school & 1.83 & 0.28 \\
High school & 0.65 & -- \\
some college & -- & 0.11 \\
College & 3.78 & 0.87 \\
Non-housing wealth quartile lowest & 1.14 & -- \\
$\quad 2$ & -- & 0.83 \\
$\quad 3$ & 0.91 & 0.28 \\
$\quad 4$ & 1.59 & 0.00 \\
Age $<55$ & 6.91 & 0.13 \\
$55-59$ & 0.29 & 0.14 \\
$60-64$ & 0.45 & 0.98 \\
$75+$ & 0.99 & 0.39 \\
\hline
\end{tabular}

Source: Authors' calculations 